\title{
サポニン潅流法による前庭感覚上皮細胞の細胞骨格構造の観察
}

\author{
工田 昌矢 ${ }^{1)} \cdot$ 宮脇 浩紀 ${ }^{2)} \cdot$ 原田 康夫 ${ }^{3)}$
}

\section{Cytoskeletal Organization of the Vestibular Sensory Epithelia Revealed by Using Saponin Perfusion Method}

\author{
Masaya Takumida \\ (WFAC Hiroshima General Hospital) \\ Hironori Miyawaki \\ (Hiroshima University) \\ Yasuo Harada \\ (Hiroshima University)
}

The cytoskeletal organization of the guinea pig vestibular sensory epithelial cells was investigated using the saponin perfusion method under a scanning electron microscope. The skeletal framework of a cell is composed of thin (actin or intermediate filaments) and thick filaments (microtublues). The membrane bound organelles such as the nucleus, mitochondria, endoplasmic reticulum, Golgi apparatus, secretory granules, desmosomes etc. were also well demonstrated. This facilitates investigation of three-dimensional structures of cytoskeletons as well as their complex interactions with various membranes bound organelles. Therefore, this technique may provides further information about distribution, topographic relationships and the functional role of cytoskeletons.

Key words: cytoskeleton, vestibule, scanning electron microscopy, inner ear, guinea pig

\begin{abstract}
緒 言
前庭感覚上皮の細胞内構造の三次元的観察は これまで主として走査電顕を用いて成されてお り, 感覚細胞あるいは支持細胞の内部のミトコ ンドリア, 小胞体, ゴルジ装置といった膜性の 小器官の構造については明瞭に描出されてい る1). 一方, 近年, 細胞内の線維状構造, 寸な わち細胞骨格に対する関心が内耳でも大きくな ってきて扣り，その構造や機能についても種々
\end{abstract}

の研究が成されている2) 99. 細胞骨格は細胞を 構造的に支持する細胞質要素として細胞あるい は細胞内構造の形態，機能に強く関わっている. これら細胞骨格を主として構成する要素として は微小管, 中間径フィラメント，アクチンフィ ラメントの 3 種の線維性構造があり, 加えてそ れらを連結する多くの構造がある.これらのフ ィラメントは細胞内で複雑なネットワークを形 成して扣り細胞の機能に強く関与している. 前

1）広島県厚生農業協同組合連合会広島総合病院耳鼻咽喉科

2) 広島大学医学部耳鼻咽喉科学教室

3) 広島大学 
庭感覚上皮細胞の形態と機能に関してはこれま で電顕, 或いは組織化学的手法を用いて様々な 研究が行われているがその細胞骨格構造, とり わけその三次元的配列については不明な点が数 多く残されている，そこで，今回，我々はサポ ニン潅流法を用いて前庭感覚上皮細胞細胞骨格 の三次元構造を走査電顕により観察したので報 告する.

\section{研究方法}

実験にはプライェル反射正常の成熟，有色乇 ルモット(体重 250〜300 g) を使用した. 動物 はネンブタールにて深麻酔後0.1\%サポニンを

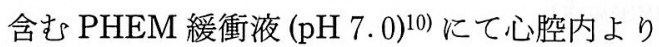
潅流の後, 直ちに側頭骨を摘出し, 末梢前庭器 を摘出した。試料は0.1\%サポニンを含む $0.5 \%$ グルタールアルデヒド， $0.5 \%$ パラホルムアル デヒドの等量混液 (PHEM 緩衝液, $\mathrm{pH} 7.0$ ) て15分間固定した。ついで，25\% dimethyl sulfoxide (DMSO) にて30分間，50\% DMSO に て 1 時間置換後, 液体窒素中で涷結割断を行い $0.5 \%$ オミウム酸 $(0.1 \mathrm{M}$ リン酸緩衝, $\mathrm{pH}$ 7.0 ) そて後固定， $0.5 \%$ タンニン酸，0.5\%才 スミウム酸にて導電染色後, エタノール系列に て脱水, t-butyl alcohol 凍結乾燥を行い, 白金 にて $20 \mathrm{~A}$ の厚さでスパッタコーティングを施

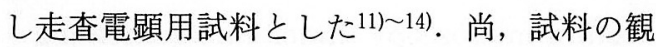
察にはHitachi S800 形走査電顕を加速電圧 25 kvで使用した。

\section{結 果}

サポニン潅流法を使用して末梢前庭器の試料 作製を行った結果, 細胞内の膜性構造物に加え て種々の線維状構造物の観察が可能であった.

弱拡大では透過電顕像と同様に感覚細胞, 支 持細胞扣よびそれらの附属器官が明瞭に観察さ れた(図 1). 微細構造の保存状態はサポニン処 理の効果によって異なり, 効果の高い細胞とそ らでない細胞とがモザイク状に混在していた. サポニン処理の効果の高い細胞で認められた細 胞内の線維状構造はその径と分布状態上り太径 フィラメントと細径フィラメントの 2 種類に分
類された.太径フィラメントの直径は 25〜30 $\mathrm{mm}$ (真の直径十白金コーティング)で, 一般に まっすぐで，分枝や吻合をせず，しばしば幾本 ものフィラメントが束になって走行していた. 細径フィラメントは直径 $10 \sim 20 \mathrm{~nm}$ (白金コー ティングを含む)でしばしば他のフィラメント と分枝, 吻合し, 非常に複雑な網状構造を呈し ていた.これらのフィラメントの㴗とんど，と りわ壮細径フィラメントは顆粒様物質で修飾さ れ直径 10〜 $40 \mathrm{~nm}$ になっていた。 それゆ克各 々のフィラメントの直径の計測は顆粒様物質の 認められない場所で行った(図 2，3).

サポニン処理の効果の高い上皮細胞では細胞内 構造の大部分はサポニン処理のため消失してい た. 核周囲部では多数の細径フィラメントが認 められ，核外膜と小胞体，ミトコンドリアなど の細胞内小器官とを結び付けて拉り, 加兄て, これらのフィラメントはしばしば細胞膜と直接 連絡していた(図 2 ). サポニン処理の効果の弱 い他の細胞では核, ミトコンドリア, 細胞膜, 細胞内フィラメントのみならず分泌顆粒や粗面 小胞体, ゴルジ装置, ミトコンドリアなどの細

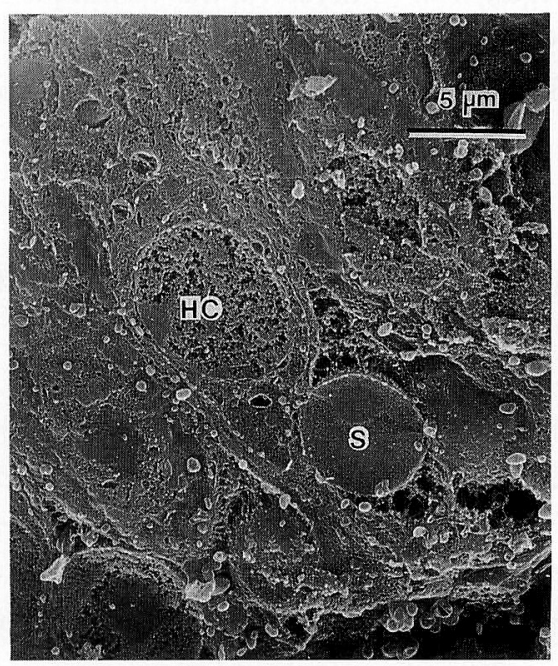

図 1 弱拡大では透過電顕像と同様に感覚細 胞 $(\mathrm{HC})$, 支持細胞 $(\mathrm{S})$ 和よびそれら の附属器官が明瞭に観察される. 
胞内小器官もよく保存されていた(図 3 ).

感覚細胞ではその蓋板は細径フィラメントの 特徵的な網状構造により構成され蓋板下部に存 在する太径フィラメントと連続していた。 太径 フィラメントは細胞頂部でミトュンドリアと密 接な関係を有し細胞体の長軸方向に平行に配列 していた.これらのミトュンドリアはしばしば 細径フィラメントの網目の中にもぐり込んでお りまたミトコンドリア外膜に直接付着するフ イラメントも観察された(図 4 ).

支持細胞の内部には分泌顆粒と考克られる数 多くの顆粒様構造が観察されその中には透過電 顕で認められるものと同様な小線維状の構造が 認められた。これらの分泌顆粒は, 細胞の長軸 方向に走る太径フィラメントと密接な関係を有 していた．さらに分泌顆粒どうしが互いに細径 フィラメントにより連結されている像や分泌顆 粒と小胞体，ミトコンドリア，核などの細胞内 の膜性の小器官とが細径フィラメントにより結

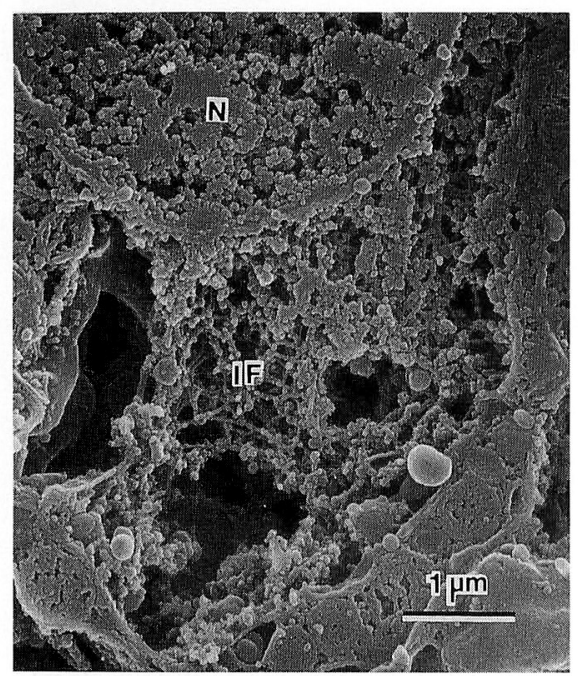

図 2 核周囲部には多数の細径フィラメント (IF) が認められ，核外膜と小胞体， : トコンドリアなどの細胞内小器官とを 結び付けて打り, 加えて, これらのフ ィラメントはしばしば細胞膜と直接連 絡している. $\mathrm{N}$ ：核

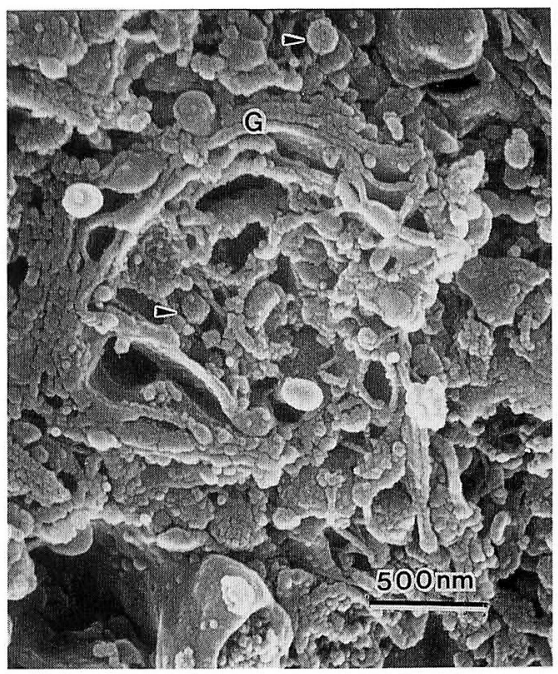

図 3 ゴルジ装置 $(\mathrm{G})$ の周囲では細径フィラ メント，太径フィラメントが明瞭に観 察されその周用にクラスリンに被覆さ れた典型的な蜂巣状構造をむつコーテ イッドベジクルが付着しているのを認 める(矢頭)、ゴルジ装置周囲のフィラ メントはゴルジ装置の末端あるいは側 方で付着して拉り, 両者が密接に関係 している.

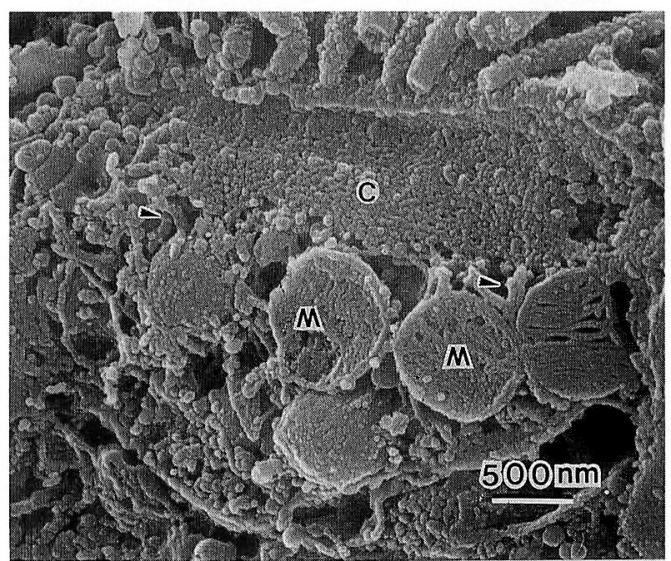

図4 感覚細胞ではその蓋板 (C) 細径フィラメ ントの特徵的な網状構造により構成され蓋 板下部に存在する太径フィラメントと連続 している(矢頭).太径フィラメントは細胞 頂部でミトコンドリア $(\mathrm{M})$ と密接な関係を 有し細胞体の長軸方向に平行に配列してい、 る. 
び付けられている像も観察された（図 5 )。ゴル ジ装置の周囲では細径フィラメント，太径フィ ラメントが明瞭に観察されその周囲にクラスリ ンに被覆された典型的な蜂巣状構造をもつュー ティッドベジクルが付着しているのを認めた. ゴルジ装置周囲のフィラメントはゴルジ装置の 末端あるいは側方で付着して扔り，両者が密接 に関係している所見も認められた(図 3 ).

これらに加えて今回, 細胞間接着構造の観察 も可能であった．支持細胞上部の網状帯の部分 は細径フィラメントの特徵的配列により構成さ れており，蓋板下部の細径フィラメントと連続 している所見，あるいはデスモゾームと考觉ら れる部分に細径フィラメントが密接に関与して いる像が認められた(図6).

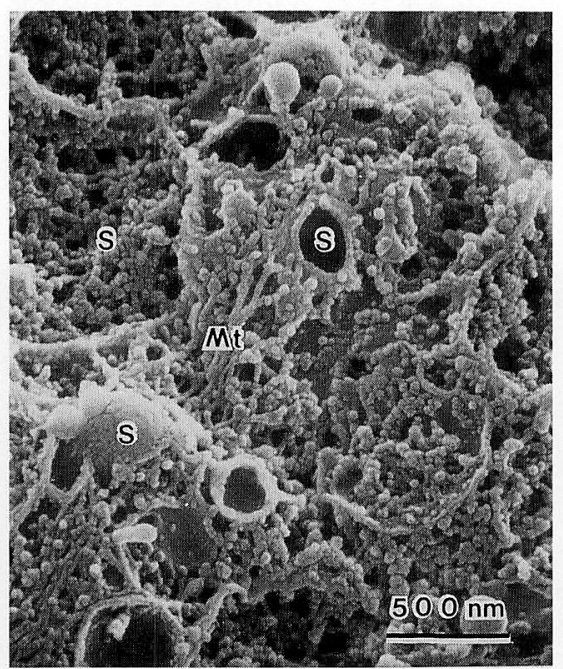

図 5 支持細胞の内部には数多くの顆粒様構 造 (S)が観察されその中には小線維状 の構造が認められる.これらの分泌顆 粒は, 細胞の長軸方向に走る太径>ィ ラメント $(\mathrm{Mt})$ と密接な関係を有して 打り，分泌顆粒どらしが互いに細径フ ィラメントにより連結されている像や 分泌顆粒と小胞体, ミトコンドリア, 核などの細胞内の膜性の小器官とが細 径フィラメントにより結び付けられて いる像も観察される。

\section{考察}

医学生物学の分野で走查電顕は主として細胞 や組織の三次元構造を観察するために用いられ てきた。 細胞や組織の表面構造は通常の試料作 製法に上り容易に観察可能であるが，その内部 構造については切断や割断をせずに観察するこ とは不可能である．細胞や組織の内部構造の観 察のために，従来，様々な試料作製法が用いら れてきたが，近年，化学的浸軟法と凍結割断法 を組み合せた方法 (A-O-D-O 法) が Tanaka ら15) によって開発され細胞内部構造の観察に 応用されている。この方法は内耳の細胞内構造 の観察にも応用され細胞内の膜性小器官の立体 構造についての詳細な検討が成されているが， 細胞骨格を中心とした細胞内の様々な線維状構 造については明らかになっていない1)。一般に

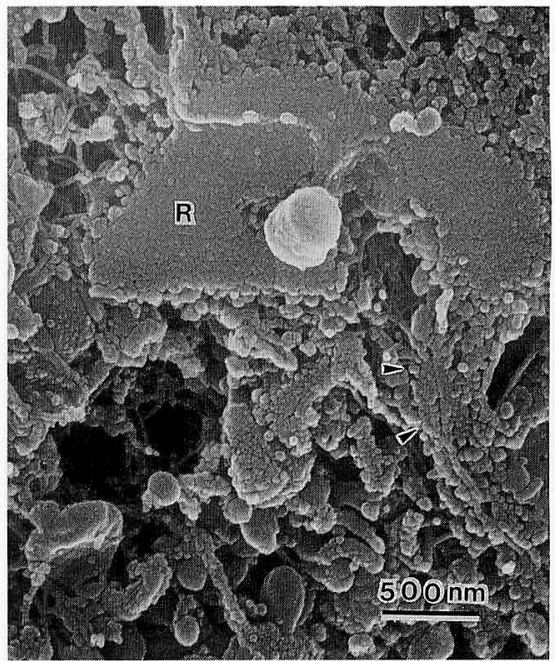

図 6 支持細胞上部の網状帯 $(\mathrm{R})$ の部分は細 径フィラメント径の特徽的配列により 構成されており, 蓋板下部の細径フィ ラメントと連続している所見，あるい はデスモゾームと考壳られる部分に細 径フィラメントが密接に関与している 像が認められる(短)。 
細胞骨格と称される細胞内線維状構造について は内耳でも透過電顕を利用して急速凍結, デ ィープェッチング法により観察されている が677), その結果は満足するものではなく前庭 感覚上皮の内部構造, とりわけ細胞骨格とその 他の種々の膜性の小器官との関連については未 だ不明な点が数多く残されている。この点を解 決するために今回我々はすでに他の組織で試み られており, 細胞内の線維状構造のみならず膜 性構造をる描出することが可能であるサポニン 潅流法 ${ }^{11)}$ と凍結割断法とを組み合せて内耳の 試料作製を行い走査電顕にて観察したところ良 好な結果を得ることができた.

今回の方法で試料作製を行った結果, 前庭感 覚上皮の細胞骨格フィラメントは走査電顕によ り明瞭に観察可能となった。微細なフィラメン トにより構成される複雑な網目状構造は Wolosewick ら ${ }^{16)}$ により提唱された微細柱格子 (microtrabecullar lattice) に一致していた。乾燥試料 は白金で約 $2 \mathrm{~nm}$ の厚さのコーティングを施さ れているため, 走査電顕により観察された細径, 太径フィラメントの真の直径は細径フィラメン トで $5 \sim 15 \mathrm{~nm}$, 太径フィラメントで $20 \sim 30$ nmであった。細胞骨格を主として構成する微 小管は直径が約 $25 \mathrm{~nm}$ で分岐，吻合をせずほ ぼまっすぐに走行し，アクチンフィラメントの 直径は $7 \mathrm{~nm}$, 中間径フィラメントの直径は 10 $\mathrm{nm}$ であることが知られている.このことから 今回, 走査電顕で観察された太径フィラメント は微小管と考兄られた。一方, アクチンは前庭 感覚上皮, 特に前庭感覚細胞の蓋板や前庭支持 細胞の網状帯に分布すること4) 7) や, 種々の夕 イプの中間径フィラメントが既に末梢前庭器に 存在することが証明されている2)3)ことより， 今回認められた細径フィラメントはアクチンフ ィラメントと中間径フィラメントの両者を含ん でいると考えられた。

細胞骨格フィラメントの周りを取り囲んでい る顆粒様物質の大部分は細胞内の種々の可溶性 蛋白と考号られる. Triton X-100 やサポニンな
どは細胞膜を溶出(前者)あるいは膜に穴をあけ (後者)細胞質内の可溶性蛋白質を洗いだし顆粒 様物質の量を減少させる。このような化学的膜 処理は走査電顕での観察や急速凍結, ディープ エッチング法1718) に非常に有用となる。加え て化学的膜処理により可溶性蛋白質を取り除く ことにより細胞骨格フィラメントのコントラス トを引き上げる効果もある。このような処理が なんらかのアーチファクトを引き起こす可能性 も否定できないが, 今回の得られた結果がこれ までの同様の試料で異なる試料作製法により得 られた結果と一致していることより膜性構造と の位置関係は保たれているものと考えられ

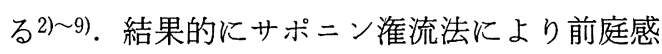
覚上皮の細胞骨格が走査電顕を利用して観察可 能となり，この方法は細胞骨格の位置関係や分 布, 機能に対するより詳細な情報を与えてくれ

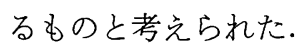

\section{参考文献}

1) Harada $Y$, Tagashira $N$, Takumida $M$, et al : Three-dimensional structures of the vestibular sensory epithelia. Acta Otolaryngol (Stockh) $99: 411 \sim 418,1985$.

2) Thornell L-E, Anniko $M$ and Virtanen I : Cytoskeletal organization of the human inner ear. I. Expression of intermediate filaments in vestibular organs. Acta Otolaryngol (Stockh) Suppl $435:$ 5 27, 1987.

3) Bauwens LJJM : Intermediate filament proteins in the human audio-vestibular organ. An immunohistochemical study. Thesis, Utrecht, 1991.

4) Flock $\AA$ and Cheung $\mathrm{H}$ : Actin filaments in sensory hairs of the inner ear receptor cells. J Cell Biol 75 : 339 343, 1977.

5) Flock $\AA$, Cheung H, Flock B, et al : Three sets of actin filaments in sensory cells of the inner ear; identification and functional orientation determined by gel electrophoresis, immunofluorescence, and electron microscopy. J Neurocytol $10:$ 133 147, 1981.

6) Arima $T$, Uemura $T$ and Yamamoto $T$ : Three- 
dimensional visualization of the inner ear hair cell of the guinea pig; a rapid-freeze, deepetch study of filamentous and membranous organelles. Hear Res 25 : 61 68, 1987.

7) Hirokawa $N$ and Tilney LG : Interactions between actin filaments and between actin filaments and membranes in quick-frozen; deeply-etched hair cells of the chick ear. J Cell Biol 95 : 249 261, 1982.

8) Favre D and Sans A : Organization and density of microtubules in the vestibular sensory cells in the cat. Acta Otolaryngol (Stockh) $96: 15 \sim$ 20, 1983.

9) Kikuchi T, Takasaka T, Tonosaki A, et al : Microtubule subunits of guinea pig vestibular epithelial cells. Acta Otolaryngol (Stockh) Suppl $481:$ 107 111, 1991.

10) Schliwa $M$ and Van Blerkom J : Structural interaction of cytoskeletal components. J Cell Biol 90 : 222 235, 1981.

11) Fukudome $H$ and Tanaka $K$ : Saponin perfusion method for observing intracellular structures by SEM. Biomedical SEM $19: 66 \sim 71$, 1990.

12) Senda $T$, Ban $T$ and Fujita $H$ : Scanning electron microscopy of cytoplasmic filaments in rat anterior pituitally cells. Arch Histolcytol 52 : $371 \sim 378,1988$.

13) Sasaki J, Watanabe S, Nomura T, et al : A per- fusion method using low concentration of glutaraldehyde and saponin solution for the observation of the cytoskeleton of epithelial cells. J Electron Microsc 37 : 38 44, 1988.

14) Okanoue TM, Ohta S, Fushiki OOu, et al : Scanning electron microscopy of the liver cell cytoskeleton. Hepatology $5: 1 \sim 6,1985$.

15) Tanaka $K$ and Naguro $T$ : High resolution scanning electron microscopy of cell organelles by new specimen preparation method. Biomedical Res Suppl 2 : 63 70, 1981.

16) Wolosewick JJ and Porter KR : Stereo high voltage electron microscopy of whole cells of the human diploid line, WI-38. Amer J Anat $147: 303 \sim 324,1976$.

17) Hirokawa $N$ and Heuser JE : Quick-freeze, deep-etch visualization of the cytoskeleton beneath surface differentiations of intestina; epithelial cells. J Cell Biol 91 : 399 409, 1981.

18) Hirokawa $N$ : Cross-linker system between neurofilaments, microtubules, and membranous organelles in frog axons revealed by the quick-freeze, deep-etching method. J Cell Biol 94 : 129 142, 1982.

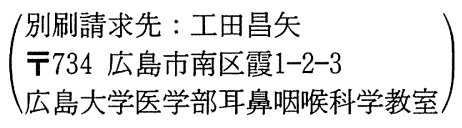

